\title{
Morphological, ecological and toxicological aspects of Raphidiopsis raciborskii (Cyanobacteria) in a eutrophic urban subtropical lake in southern Brazil
}

\author{
Vera Regina Werner 1,*(i), Andréa Tucci ${ }^{2}$ (i), Lisangela Marques da Silva', João Sarkis Yunes ${ }^{3}$ (i), \\ Emanuel Bruno Neuhaus ${ }^{4}$ (D), David E. Berthold ${ }^{5}$ (i) \& H. Dail Laughinghouse IV ${ }^{5}$ (D)
}

\author{
'Natural Sciences Museum, Secretary of the Environment and Infrastructure, \\ Rua Dr Salvador França 1427, 90690-000, Porto Alegre, RS, Brazil. \\ *vera-werner@sema.rs.gov.br \\ IInstitute of Botany, Phycology, Av. Miguel Estefano 3687, 04301-012, São Paulo, SP, Brazil. \\ ${ }^{3}$ Laboratory of Cyanobacteria and Phycotoxin, Institute of Oceanography, Federal University of Rio Grande \\ Rua Padre Nilo Gollo, 96203-270, Rio Grande, RS, Brazil \\ ${ }^{4}$ National Museum, Federal University of Rio de Janeiro, Ichthyology Section, \\ Quinta da Boa Vista s/n, São Cristóvão, 20940-040, Rio de Janeiro, RJ, Brazil. \\ ${ }^{5}$ Fort Lauderdale Research and Education Center, University of Florida / IFAS, 3205 College Avenue, Davie, FL, USA.
}

Recebido em 05.VIII.2019

Aceito em 28.VII.2020

DOI 10.21826/2446-82312020v75e2020018

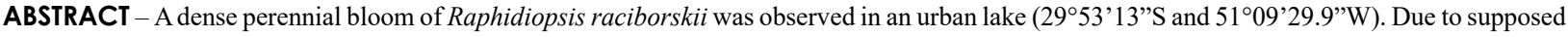
toxicity, this study analyzed the morphology of the species, evaluated the main factors that influence its growth, and examined bloom toxicity. Two sites were sampled monthly from November 2009 to November 2010. The species was found in all samples and dominated in $77 \%$ of the samples. Highest density was recorded at the end of summer (March $-199,550$ ind. $\mathrm{mL}^{-1}$ ) at $26.6^{\circ} \mathrm{C}$ and $\mathrm{pH} 7.8$. High densities were also found at low temperatures $\left(72,145\right.$ ind. $\mathrm{mL}^{-1}$ at $12.6^{\circ} \mathrm{C}$ and 130,475 ind. $\mathrm{mL}^{-1}$ at $14.5^{\circ} \mathrm{C}$ ) and at minimum (5.4) and maximum (8.7) $\mathrm{pH}$, reaching 89,964 ind.mL $\mathrm{mL}^{-1}$ and 61,400 ind. $\mathrm{mL}^{-1}$, respectively. Nitrogen availability was high, especially ammonium [(60-)140-660 $\left.\mu \mathrm{g} . \mathrm{L}^{-1}\right]$, and phosphorus was low (orthophosphate $<10$ $\left.\mu \mathrm{g} . \mathrm{L}^{-1}\right)$. These results support that $R$. raciborskii has a wide tolerance to abiotic variations. Saxitoxins and gonyautoxins were found in the bloom.
\end{abstract}

Keywords: cyanobacterial bloom, Cylindrospermopsis raciborskii, neurotoxins

RESUMO - Aspectos morfológicos, ecológicos e toxicológicos de Raphidiopsis raciborskii (Cyanobacteria) em um lago subtropical urbano e eutrófico no extremo sul do Brasil. Densa e perene floração de Raphidiopsis raciborskii foi observada em um lago urbano (2953'13"S e $51^{\circ} 09^{\prime} 29,9^{\prime \prime}$ ). . Devido à suposta toxicidade, esse estudo analisou a morfologia da espécie, avaliou os principais fatores que interferem no seu crescimento e examinou a toxicidade da floração. Dois locais foram amostrados mensalmente entre novembro de 2009 e novembro de 2010 . A espécie foi encontrada em todas as amostras, dominante em $77 \%$. A maior densidade foi registrada no final do verão $\left(\right.$ março -199.550 ind. $\left.\mathrm{mL}^{-1}\right)$ a $26,6^{\circ} \mathrm{C}$ e pH 7,8. Altas densidades também foram observadas sob baixas temperaturas $\left(72.145\right.$ ind. $\mathrm{mL}^{-1}$ a $12,6^{\circ} \mathrm{C}$ e 130.475 ind. $\mathrm{mL}^{-1}$ a $\left.14,5^{\circ} \mathrm{C}\right)$ e no $\mathrm{pH}$ mínimo $(5,4)$ e máximo $(8,7)$ registrado, atingindo 89.964 ind. $\mathrm{mL}^{-1}$ e 61.400 ind. $\mathrm{mL}^{-1}$, respectivamente. A disponibilidade de nitrogênio foi alta, especialmente amônio [(60-)140-660 $\left.\mu \mathrm{g} . \mathrm{L}^{-1}\right]$, e a de fósforo foi baixa (ortofosfato $<10 \mu \mathrm{g} . \mathrm{L}^{-1}$ ). Esses resultados sustentam que $R$. raciborskii tem uma ampla tolerância a variações abióticas. Saxitoxinas e goniautoxinas foram detectadas na floração.

Palavras-chaves: Cylindrospermopsis raciborskii, florações de cianobactérias, neurotoxinas

\section{INTRODUCTION}

Raphidiopsis raciborskii (Woloszynska) Aguilera, Berrendero, Gómez, Kaštovský, Echenique \& Salerno is synonymous to Cylindrospermopsis raciborskii (Woloszynska) Seenayya \& Subba Raju was originally described as Anabaena raciborskii by Woloszynska (1912) from plankton of a small tropical lake in Java (Indonesia). The species was transferred to Anabaenopsis Miller 1923 [=Anabaenopsis raciborskii (Woloszynska) Elenkin] due to terminal heterocytes, and later Seenayya \& Subba Raju (1972) transferred it to Cylindrospermopsis due to the origin of apical heterocytes. Thus, Cylindrospermopsis was defined based on the heterocyte origin and position, while the genus Raphidiopsis Fritsch \& Rich 1929 lacked heterocytes (Komárek \& Anagnostidis 1989). However, Komárková (1998) mentioned that due to heterocytes and akinetes usually being rare, sterile trichomes of Cylindrospermopsis were easily confused with Raphidiopsis. Using a $16 \mathrm{~S}$ rRNA gene phylogeny, Moustaka-Gouni et al. (2009) proposed that $R$. mediterranea from Lake Kastoria, Greece (type locality) was actually a non-heterocytous stage of C. raciborskii. Aguilera et al. (2018) found that strains of Raphidiopsis and Cylindrospermopsis were within a 
single clade, and not genetically different using both $16 \mathrm{~S}$ rRNA gene phylogeny and the secondary structure of the 16S-23S rRNA internal transcribed spacer (ITS). Due to the principle of priority, these authors synonymized the genus into Raphidiopsis Fritsch \& Rich emend. Aguilera, Gómez, Kăstovský, Echenique \& Salerno.

Raphidiopsis raciborskii (= Cylindrospermopsis raciborskii) is a planktonic cyanobacterium known worldwide for forming cyanobacterial harmful algal blooms (cyanoHABs). These cyanoHABs have had chronic and toxic effects, including the death of fish, humans and other animals (Codd \& Bell 1984, Falconer \& Fitzgerald 1999). This cyanobacterium is increasingly found in tropical and temperate environments of both the Northern and Southern Hemispheres and is considered exotic and invasive (McGregor \& Fabbro 2000, Briand et al. 2004, Jones \& Sauter, 2005, Kokociński et al. 2010, Antunes et al. 2015, Babanazarova et al. 2015). The species is on the list of invasive plants/algae in some states within the U.S. (e.g. Indiana and Wisconsin), where dedicated remediation efforts for its control are established. It is common in fresh waters, but also occurs in swamps and slightly brackish waters (1.5-2\%o) (Padisák 1997, Antunes et al. 2015). In the 1990 's, there was an expansion of the species throughout Brazil due to eutrophication (Tucci \& Sant'Anna 2003), and it is now ubiquitous in both tropical and subtropical regions of the country. Most work on this species (including toxicology) is from blooms of Brazilian waters (e.g. Lagos et al. 1999, Bouvy et al. 2000, Molica et al. 2002, Costa et al. 2006, Gemelgo et al. 2008, Hoff-Risseti et al. 2013).

Since $R$. raciborskii is ecologically and toxicologically important, information on its dense bloom structures in lakes used for recreation or as a resting/breeding area for wildlife is fundamental for proper management. Therefore, we analyzed the morphological variability of the species, temporal and spatial variation of its density, key factors for its development, and bloom toxicity, in order to attain a better understanding of this species.

\section{MATERIALS AND METHODS}

\section{Study area}

The studied lake (29 53'13"S and 51 $\left.{ }^{\circ} 09^{\prime} 29.9^{\prime \prime} \mathrm{W}\right)$ is the main water body at the Lutheran University of Brazil (ULBRA) located in Canoas, Rio Grande do Sul, southern Brazil. It was constructed about 20 years ago in a shallow area with stones, gravel and rubble and covers $10,150 \mathrm{~m}^{2}$ with a mean depth of $3.5 \mathrm{~m}$. The lake is supplied by rainwater and runoff from gutters and roofs (via underground pipes), and its east bank is shaded by shoreline trees [Inga uruguensis Hook et Arn., Senna multijuga (LC Rich.) Irwin \& Barn., Psidium cattleianum Sat., and Pittosporum undulatum Vent.]. Turtles, fish and birds are found in the lake and there is a small island that is a resting and breeding area for wildlife. This lake is in a place used for recreation and leisure due to its scenic beauty and central location (Figure 1).

\section{Sampling}

Collections were carried out monthly between November 2009 and November 2010, at two sites, one at the inflow of the water (I) and the other at the outflow (O) $(n=26)$ (Figure 1). For taxonomic analyses, samples were taken with a plankton net $(30 \mu \mathrm{m})$ and for quantitative counts the surface of the water was sampled via a grab sample; these were fixed with $4 \%$ formaldehyde and Lugol's solution, respectively. The samples are deposited in Prof. Dr. Alarich R.H. Schultz Herbarium (HAS) of the Natural Sciences Museum (MCN), Porto Alegre, Rio Grande do Sul state, Brazil, under accession numbers HAS 108645 to HAS 108702. Concentrated subsamples were kept unfixed for the analysis of live material and microphotographs.

Abiotic variables such as $\mathrm{pH}$, water temperature $\left({ }^{\circ} \mathrm{C}\right)$ and air temperature $\left({ }^{\circ} \mathrm{C}\right)$ were measured in the field using a portable potentiometer (EC 10 Model 50050), electrical conductivity $\left(\mu \mathrm{S} . \mathrm{cm}^{-1}\right)$ was measured with a conductivity meter (Model YSI 30), and depth (m) and transparency (m) using a Secchi disc. Samples for the analysis of organic matter $\left(\mathrm{mg} . \mathrm{L}^{-1}\right)$, ammonium $\left(\mu \mathrm{g} . \mathrm{L}^{-1}\right)$, nitrate $\left(\mu \mathrm{g} . \mathrm{L}^{-1}\right)$, nitrite $\left(\mu \mathrm{g} . \mathrm{L}^{-1}\right)$, orthophosphate $\left(\mu \mathrm{g} . \mathrm{L}^{-1}\right)$, dissolved oxygen $\left(\mathrm{mg} . \mathrm{L}^{-1}\right)$ and dissolved oxygen saturation (\%) were kept refrigerated and analyzed following standard methods (APHA 2005).

\section{Taxonomic analysis}

Taxonomic studies were performed using a LEICA DMLB light microscope and the photographs were taken from the ocular using a digital camera. Quantitative analyses were carried out using an inverted light microscope WILD M40, following Utermöhl (1958). Sedimentation chambers of $10 \mathrm{ml}$ were used, and the sedimentation time was 6 hours. Counts were performed by vertical transects and the limit of counted fields was calculated based on Pappas \& Stoermer (1996).

\section{Statistical analysis}

We followed the criteria established by Lobo \& Leighton (1986) to determine abundance and dominance, where the taxa whose numerical occurrence exceeds the mean number of individuals per species are considered abundant, and dominant are those that are more than $50 \%$ of the total number of individuals counted in a sample.

Ordination of abiotic data was carried out using Principal Component Analysis (PCA) (covariance matrix) to determine the variability of environmental data in relation to the study period (Valentin 2000). The analysis was done using PC-ORD version 6 for Windows. 


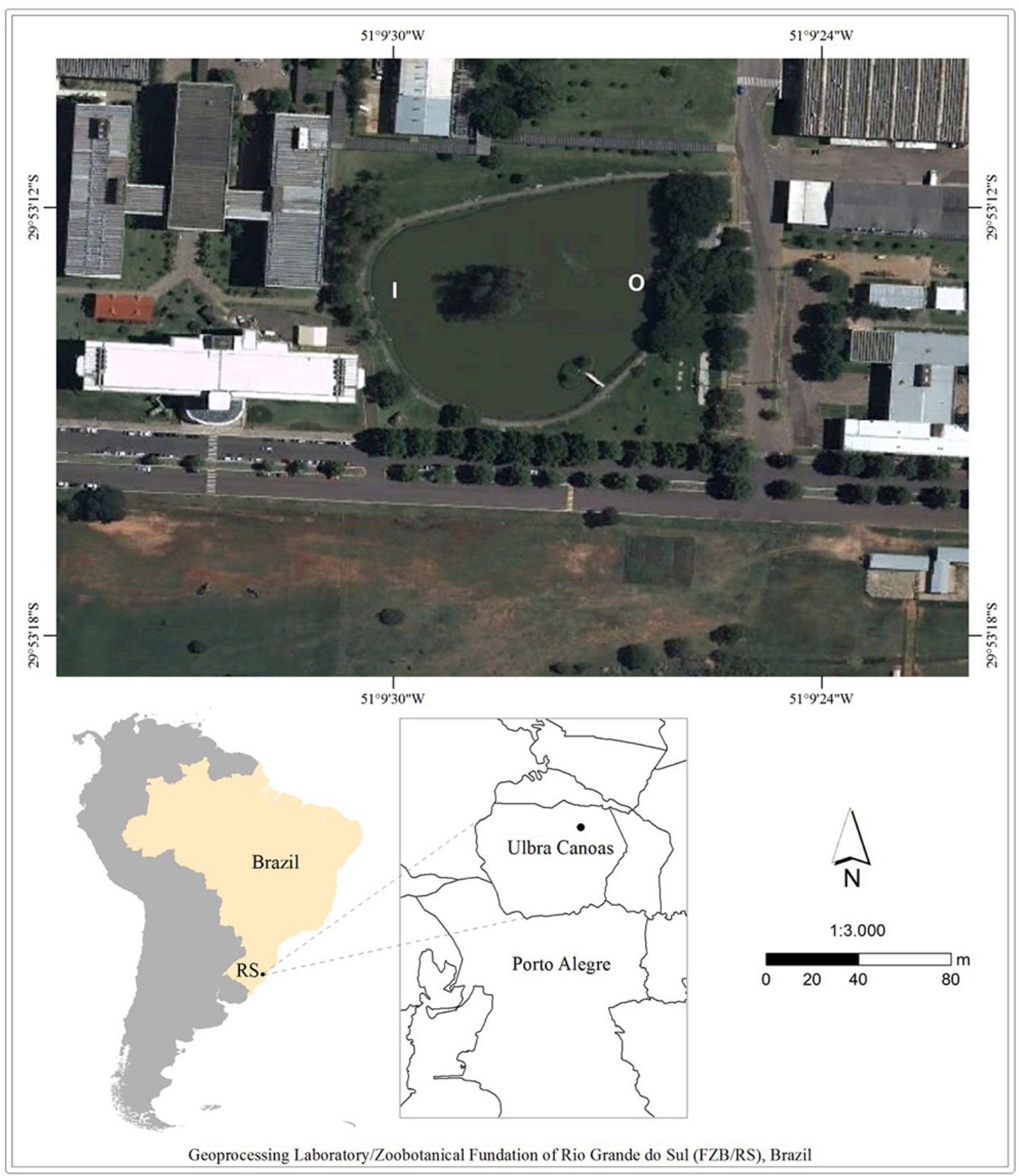

Fig. 1. Map of the studied lake, showing the two sampling sites $(\mathrm{I}=$ water inflow and $\mathrm{O}=$ water outflow).

\section{Cyanotoxin analysis}

Surface samples were collected at two sites to determine cyanotoxins, water inflow (I) and water outflow $(\mathrm{O})$, in November 2010. A $10 \mathrm{ml}$ aliquot of the sample was acidified (pH 2) with $0.05 \mathrm{M}$ hydrochloric acid. Saxitoxins were detected by High Performance Liquid Chromatography with fluorescence detection (HPLC-FLD, Shimadzu, Japan), following the post-column derivatization methodology recommended by Oshima (1995) and compared to standards of seven variants provided by NRC Research Council, Canada.

\section{RESULTS AND DISCUSSION}

\section{Community structure}

Cyanobacteria were the most abundant group of phytoplankton during the study, with more than $90 \%$ of total density in $73 \%$ of the analyzed samples $(n=26)$ (Figure 2). Raphidiopsis raciborskii was found in all samples with $85 \%$ of total community density $\left(2,166,777\right.$ ind. $\left.\mathrm{mL}^{-1}\right)$, capable of changing the color of the water to greenish-yellow and yellow. The species was dominant in $77 \%$ of the samples and abundant in $15 \%$ of the samples. The highest densities 
were seen at the end of summer (March 2010: 199,550 ind. $\mathrm{mL}^{-1}$ ) and in mid-autumn (May 2010: 169,191 ind. $\mathrm{mL}^{-1}$ ), near the inflow of the water, and the lowest densities were found at the end of spring (December 2009: inflow: 482 ind. $\mathrm{mL}^{-1}$ and outflow: 737 ind. $\mathrm{mL}^{-1}$ ) (Figure 3). At that time, diatoms became more abundant than $R$. raciborskii at both sites (inflow: 24,500 ind. $\mathrm{mL}^{-1}$ and outflow: 17,644 ind. $\mathrm{mL}^{-1}$ ), with $R$. raciborskii representing only $1.5 \%$ and $3.2 \%$ of total density, respectively.
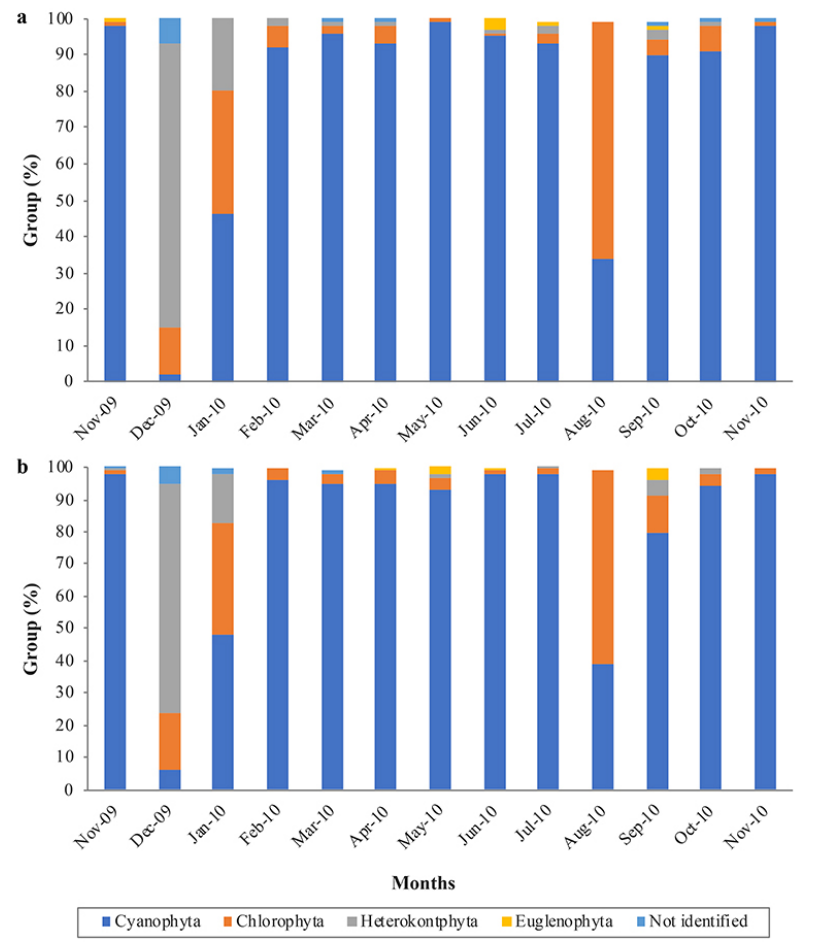

Fig. 2a, b. Bar graphs indicating the relative percentages of different phytoplankton groups in the lake inflow (a) and outflow (b), sampled every month from November 2009 to November 2010.

Chlorophytes were found in high concentrations [inflow: 93,774 ind. $\mathrm{mL}^{-1}(65.9 \%$ of the community); outflow: 111,543 ind. $\mathrm{mL}^{-1}(62.8 \%$ of the community)] in samples from August 2010. Monoraphidium irregulare (G.M.Smith) Komarková-Legnerová was responsible for the high density of chlorophytes, with 91,542 ind. $\mathrm{mL}^{-1}$ (inflow) and 108,473 ind. $\mathrm{mL}^{-1}$ (outflow). It was dominant while $R$. raciborskii was only abundant, reaching 48,562 ind. $\mathrm{mL}^{-1}$ (inflow) and 72,145 ind. $\mathrm{mL}^{-1}$ (outflow) (Figs. 2, 3). In samples collected during summer (January 2010), R. raciborskii was also abundant (inflow: 6,036 ind. $\mathrm{mL}^{-1}$; outflow: 5,061 ind. $\mathrm{mL}^{-1}$ ), along with chlorophytes (inflow: 4,891 ind. $\mathrm{mL}^{-1}$; outflow: 3,983 ind. $\mathrm{mL}^{-1}$ ) and diatoms (inflow: 2,919 ind. $\mathrm{mL}^{-1}$; outflow: 1,742 ind. $\mathrm{mL}^{-1}$ ) (Figs. 2, 3).

Planktolyngbya limnetica (Lemmermann) KomarkováLegnerová \& Cronberg and Cuspidothrix issatschenkoi (Usacev) Rajaniemi et al. were two other cyanobacteria observed in the $R$. raciborskii blooms at low densities. The highest densities of these two species were found in summer (February 2010) when P. limnetica reached 1,316 ind. $\mathrm{mL}^{-1}$ (inflow) and 1,535 ind. $\mathrm{mL}^{-1}$ (outflow) and $\mathrm{Cu}$. issatschenkoi reached 877 ind. $\mathrm{mL}^{-1}$ (inflow) and 512 ind. $\mathrm{mL}^{-1}$ (outflow). At the same time, $R$. raciborskii was much more abundant with 70,171 ind. $\mathrm{mL}^{-1}$ (inflow) and 119,218 ind. $\mathrm{mL}^{-1}$ (outflow). Planktolyngbya limnetica was present in $58 \%$ of our samples, while $C u$. issatschenkoi was only observed in 19\%. Padisák \& Reynolds (1998) found similar results while studying the phytoplankton of Lake Balaton (Hungary), where $R$. raciborskii (as $C$. raciborskii) and Cu. issatschenkoi co-occurred in $36 \%$ of their samples between 1983 and 1997.

The association of $P$. limnetica with the dominance of $R$. raciborskii has also been seen in other Brazilian water bodies, such as the Tabocas Reservoir, Caruaru, Pernambuco (Bressan 2001), Peri Lagoon, Florianópolis, Santa Catarina (Grellmann 2006) and in a lake at Prof Theobaldo Dick Park, Lajeado, Rio Grande do Sul (Hepp 2009). McGregor $\&$ Fabbro (2000) found that in Australian reservoirs the abundance of $R$. raciborskii was correlated to other species of non-heterocytous filamentous cyanobacteria [Limnothrix aff. redekei (Van Goor) Meffert, Planktolyngbya limnetica and P. subtilis (G.S. West) Anagnostidis \& Komárek]. They noted that this had also been observed for the Fitzroy River, Queensland, Australia (Fabbro \& Duivenvoorden 1996, Bormans 1999) and in different European lakes (Dokulil \& Mayer 1996, Padisák 1997, Padisák \& Reynolds 1998). Thus, finding $R$. raciborskii with other species of non-heterocytous filamentous cyanobacteria is common, with reports from temperate, tropical and subtropical environments. Niche overlaps among these species are justified by similar ecological adaptations to conditions such as low light intensity (Vörös 1995) and high levels of ammonium (Présing et al. 1996). In the studied lake, the densities of $R$. raciborskii were elevated even at the sampling site shaded by trees along the littoral zone. In $46 \%$ of the samples, the density was higher at this location (water outflow) than in the sunny water inflow, and consequently, the number of flakes migrating in the water column increased with a much thicker surface scum. The high densities of $R$. raciborskii recorded at a shaded site of the studied lake demonstrate the ecological adaptation of the species to low light intensity, corroborating the comment of Vörös (1995). Its high densities can also be justified by the excessive nitrogen availability in this site of the lake.

\section{Morphological aspects}

Throughout the study, lake water was greenish to yellowish due to the $R$. raciborskii bloom. The species sometimes formed small, yellowish flakes, that migrated in the water column and there was dense surface scum, especially at the littoral zone.

We observed straight and slightly curved trichomes in our samples. No sigmoid or spiral specimens, common in $R$. raciborskii blooms, were seen. Table 1 provides the morphological characteristics and dimensions of the analyzed specimens and figures $4 \mathrm{a}-\mathrm{c}$ illustrate the specimens. 


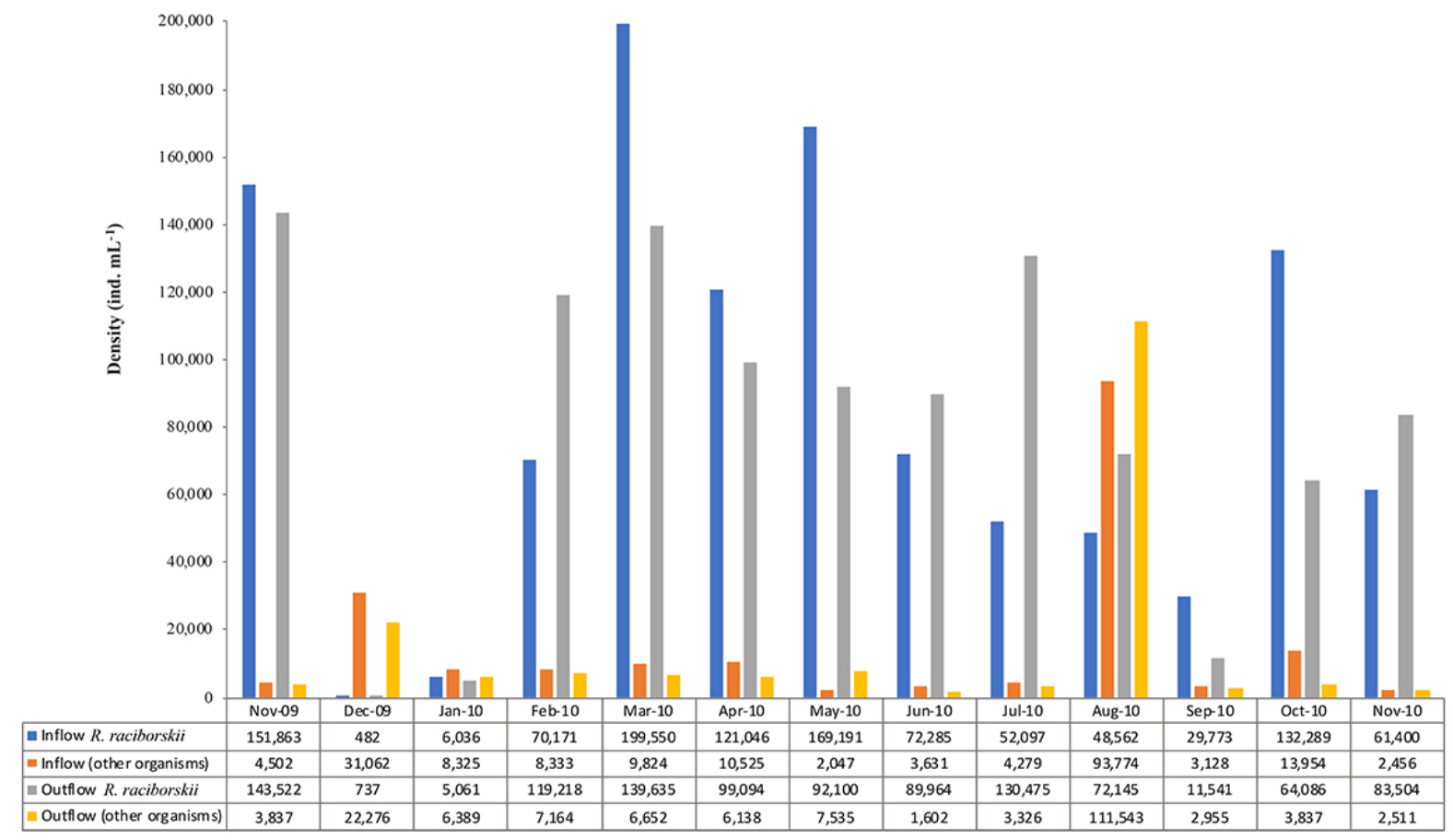

Fig. 3. Bar graphs indicating the specific densities (ind. ml-1) of Raphidiopsis raciborskii and other phytoplankton organisms (Cyanobacteria, Chlorophyta, Heterokontophyta, Euglenophyta and unidentified) sampled from the lake inflow (a) and outflow (b), every month from November 2009 to November 2010.

Table 1. Morphological and metric characteristics [minimum-maximum (mean \pm standard deviation)] of Raphidiopsis raciborskii populations in the studied lake, from November 2009 to November 2010.

\begin{tabular}{lcccc}
\hline Caracteristics & Trichome & Vegetative cell & Heterocyte & Akinete \\
\hline Form & $\begin{array}{c}\text { Solitary or entangled } \\
\text { Straight or slightly curved } \\
\text { Slightly or not constricted }\end{array}$ & $\begin{array}{c}\text { Intermediate: cylindrical } \\
\text { Apical: pointy, cylindrical, } \\
\text { or conical-round }\end{array}$ & $\begin{array}{c}\text { Conical with } \\
\text { round ends }\end{array}$ & $\begin{array}{c}\text { Cylindrical with } \\
\text { round ends }\end{array}$ \\
Width $(\mu \mathrm{m})$ & - & $2-3.5$ & $2-4$ & $2-2.5$ \\
& $(126.7 \pm 34)$ & $(2.2 \pm 0.6)$ & $(2.3 \pm 0.5)$ & $(3.1 \pm 0.6)$ \\
Length $(\mu \mathrm{m})$ & - & $2.5-9$ & $3.8-10.5$ & $(11 \pm 2.1)$ \\
Cell content & - & $(5.7 \pm 2.1)$ & $(7.7 \pm 1.9)$ & - \\
Number and position & Always with aerotopes & - & Solitary and terminal & Solitary and sub-terminal \\
Mucilage & Absent & - & Absent & Absent \\
\hline
\end{tabular}

Although $R$. raciborskii is characterized by trichomes with terminal heterocytes (originating from end cells) and subterminal akinetes, the majority of the trichomes in our populations $(94.1 \%)$ contained only vegetative cells (Fig. 5). Further, only 5.2\% $\left(114,027\right.$ ind. $\left.\mathrm{mL}^{-1}\right)$ of the populations had heterocytes at one end; no trichomes were observed with heterocytes at both ends. The amount of trichomes with akinetes was also rare; only $0.6 \%(12,163$ ind. $\mathrm{mL}^{-1}$ ) of those observed were formed by vegetative cells and an akinete, whereas only $0.02 \%\left(438\right.$ ind. $\left.\mathrm{mL}^{-1}\right)$ had heterocytes and akinetes.

We found trichomes formed by only vegetative cells in all samples (without heterocytes and/or akinetes) and this form was the densest $\left(11,314-190,954\right.$ ind. $\left.\mathrm{mL}^{-1}\right)$. In addition, populations collected between November 2009 and January 2010 were exclusively composed of vegetative cells (Fig. 5).

\section{Environmental conditions}

Principal Component Analysis (PCA) showed that there was variation in abiotic data over time, but not between the two sampling points. Temporal variation was recorded with the same pattern between the two sampling locations (water inflow and outflow). Samples from the months of July, August, September, October and November 2010 were distributed on the positive side of axis 1, associated with the highest values of organic matter (OM), electrical conductivity (Cond) and $\mathrm{pH}$ (Table 2, Fig. 6). The highest 
$\mathrm{pH}$ was recorded in spring, in October (water inflow) and November 2010 (water inflow and outflow), positive side of axis 1 . The sample sites associated to increased water temperature, corresponding to the months of January, February, March, October, and November 2010 are grouped on the negative side of axis 2 (Fig. 6).

During the study, the water temperature fluctuated between $12.6{ }^{\circ} \mathrm{C}$ (winter: August 2010) at the outflow and $28^{\circ} \mathrm{C}$ (summer: February 2010) at the inflow. The $\mathrm{pH}$ varied from acid to alkaline, with a minimum of 5.4 (winter: June 2010) at the outflow and maximum of 8.7 (spring: November 2010) at the inflow. Ammonium concentrations varied considerably with a low of 60 $\mu \mathrm{g} . \mathrm{L}^{-1}$ (spring: November 2009) at the inflow and outflow and $660 \mu \mathrm{g} . \mathrm{L}^{-1}$ (summer: December 2009) at the ouflow. Nitrate concentrations varied between 1,000 to $1,300 \mu \mathrm{g} . \mathrm{L}^{-1}$ throughout the study for both sampling. There were large differences in dissolved oxygen throughout the study, with a low of $2.5 \mathrm{mg}^{-L^{-1}}$ (winter: June 2010) at the inflow and high of $10.5 \mathrm{mg} . \mathrm{L}^{-1}$ (winter: July 2010) at the ouflow (Table 3).

High temperatures (above $23^{\circ} \mathrm{C}$ ) are one of the factors that can increase $R$. raciborskii blooms (eg. Pádisak 1997, Tucci \& Sant'Anna 2003, Gemelgo et al. 2008). However, Dokulil \& Mayer (1996) documented high densities of the species in an Austrian lagoon, where the temperatures did not exceed $18{ }^{\circ} \mathrm{C}$. Komárková et al. (1999) found a correlation between temperature and species forms, where the typical form with cylindrical cells and the characteristic presence of heterocytes developed at higher temperature. According to these authors, the optimum temperature for its growth and development has been found to be 25 ${ }^{\circ} \mathrm{C}$. Conversely, anomalous forms (elongate cells, barrelshaped, filaments with few cells, up to two cells, without heterocytes) occurred at lower temperatures $\left(15-20^{\circ} \mathrm{C}\right)$.

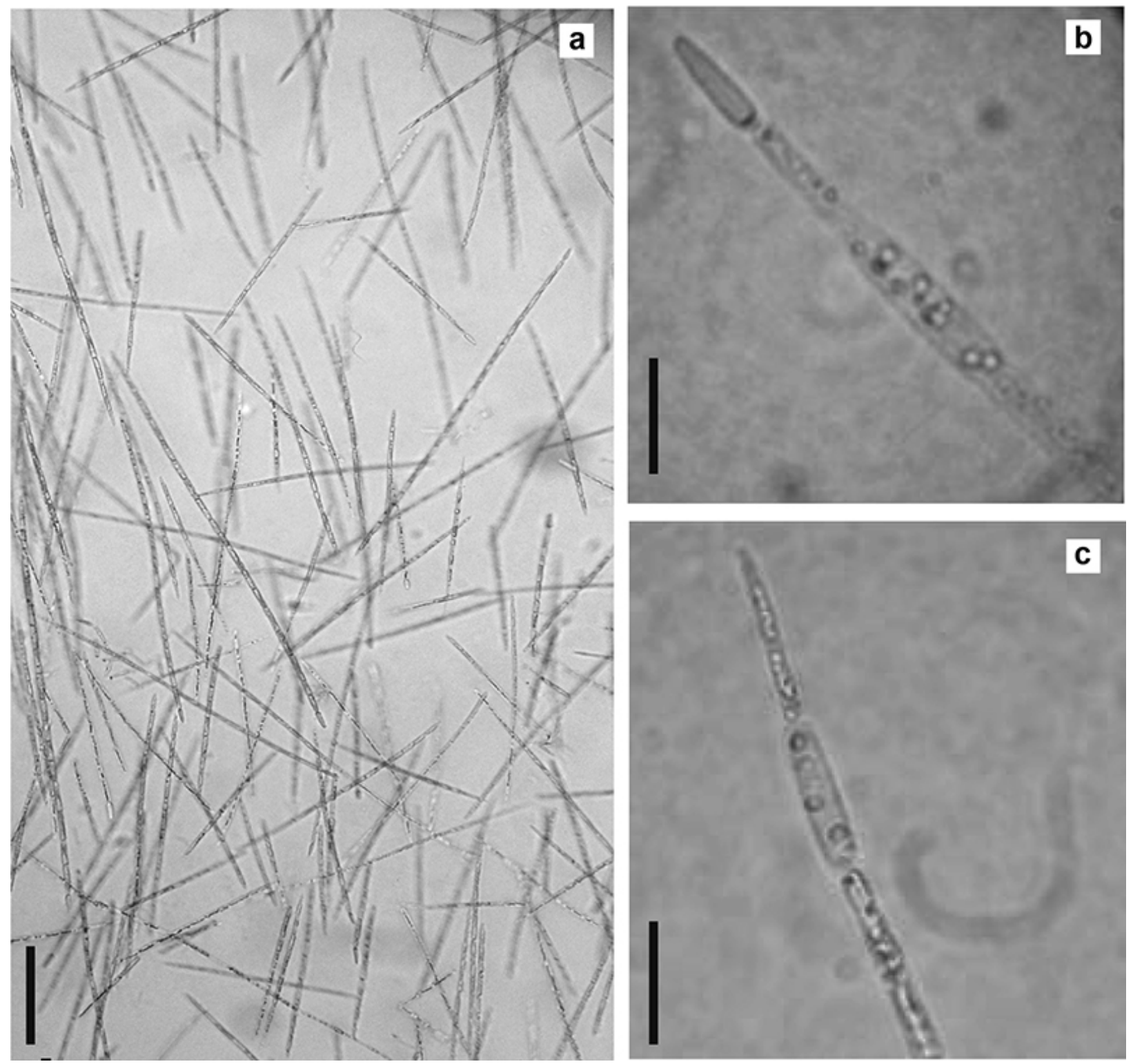

Fig. 4a-c. Photomicrographs of Raphidiopsis raciborskii bloom from the studied lake demonstrating: a. general aspect of the bloom; c. part of a trichome with a heterocyte and an akinete; c. part of a trichome with only an akinete. Bars $=10 \mu \mathrm{m}$. 


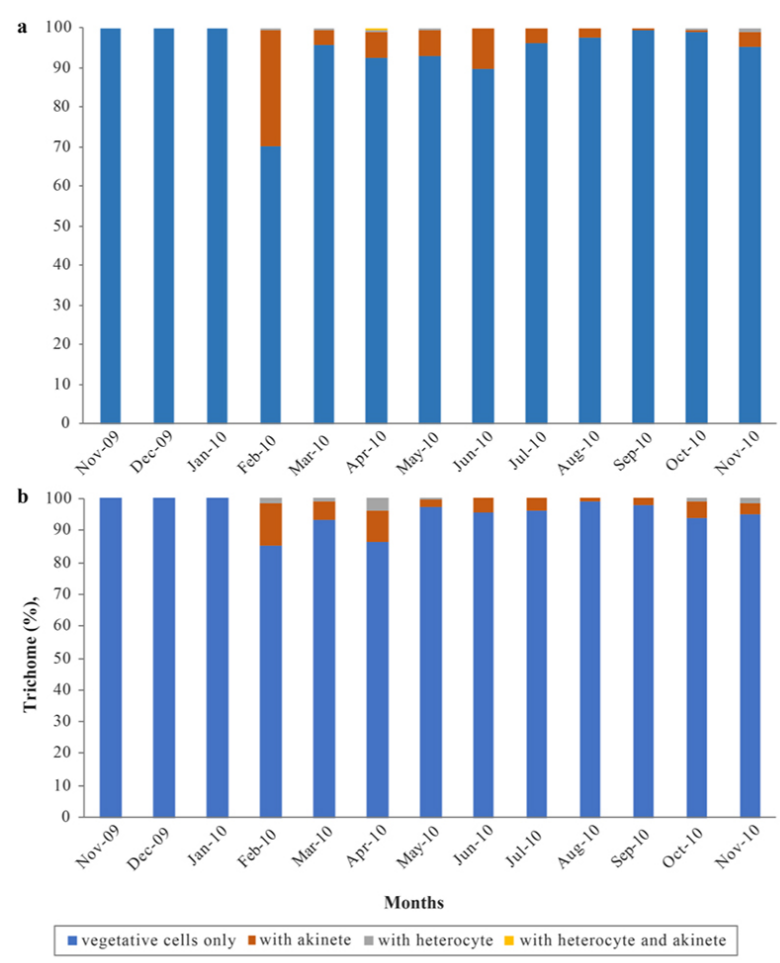

Fig. 5a, b. Bar graphs showing the percentage of Raphidiopsis raciborskii trichomes that are vegetative cells only, with akinetes, with heterocytes, or with both heterocytes and akinetes. Data represent samples taken from the lake inflow (a) and outflow (b), every month from November 2009 to November 2010.

We found high densities of $R$. raciborskii, including the formation of a yellow surface scum at low temperatures (12.6 - $15.5^{\circ} \mathrm{C}$ : June to August 2010 ), reaching 72,145 ind. $\mathrm{mL}^{-1}\left(12.6^{\circ} \mathrm{C}\right), 72,285$ ind. $\mathrm{mL}^{-1}\left(15.5^{\circ} \mathrm{C}\right)$, and 89,964 ind. $\mathrm{mL}^{-1}$ and 130,475 ind. $\mathrm{mL}^{-1}\left(14.5^{\circ} \mathrm{C}\right)$. During our study, the highest species density $\left(199,550\right.$ ind. $\left.\mathrm{mL}^{-1}\right)$ was at 26.6 ${ }^{\circ} \mathrm{C}$. Bloom occurrence at low temperatures is frequent in water bodies around the state of Rio Grande do Sul, and $R$. raciborskii is normally found throughout the year. In a subtropical lake (Lajeado, RS, 29 $27^{\prime} 52.34^{\prime \prime} \mathrm{S}$ and $\left.51^{\circ} 58^{\prime} 16.03^{\prime \prime} \mathrm{W}\right)$, the species reached 2,118 ind. $\mathrm{mL}^{-1}$ at 13.3 ${ }^{\circ} \mathrm{C}$, forming tiny flakes in the water (Hepp 2009). In a dam located in the mountains of the state of Rio Grande do Sul
(29 $9^{\circ} 3^{\prime} 30^{\prime \prime} \mathrm{S}$ and $\left.51^{\circ} 20^{\prime} 52^{\prime \prime} \mathrm{W}\right)$, high densities of the species were recorded between $11^{\circ} \mathrm{C}$ and $24^{\circ} \mathrm{C}$. However, the density when the water temperature was $11^{\circ} \mathrm{C}\left(0^{\circ} \mathrm{C}\right.$ - air $)$ was the highest found during the observed period $(100,542$ ind. $\left.\mathrm{mL}^{-1}\right)$. On the other hand, on one occasion at $24{ }^{\circ} \mathrm{C}$, the species only reached 8,211 ind. $\mathrm{mL}^{-1}$ and in another, 19 ind. $\mathrm{mL}^{-1}$ (A.T. Giordani - personal communication). These results, together with the observations by Dokulil \& Mayer (1996), support the data by Komárková et al. (1999) that $R$. raciborskii has a wide tolerance to temperature, as long as the nutrients are appropriate and there are no competitors or predators.

Nitrogen availability in the lake was high throughout the study, especially ammonium [(60-)140-660 $\left.\mu \mathrm{g} . \mathrm{L}^{-1}\right]$, which is the preferred form of nitrogen for $R$. raciborskii. Throughout our study, ammonium ranged from (60)160$630 \mu \mathrm{g} . \mathrm{L}^{-1}\left(380 \pm 150 \mu \mathrm{g} . \mathrm{L}^{-1}\right)$ - inflow and (60)140-660 $\mu \mathrm{g} . \mathrm{L}^{-1}\left(379 \pm 157 \mu \mathrm{g} . \mathrm{L}^{-1}\right)$ - outflow (Table 3). Since nitrogen was not limiting, there was no need for nitrogen fixation as a competitive strategy for $R$. raciborskii and, consequently, it was not necessary to use ATP for heterocyte formation. This justifies the low percentage (5.2\%) of trichomes with heterocytes during the study. In general, low numbers of trichomes with heterocytes are common in $R$. raciborskii blooms and have been observed in other Brazilian waters by Branco \& Senna (1994), Bouvy et al. (1999), Huszar et al. (2000) and Tucci \& Sant'Anna (2003).

Phosphorus concentrations were low throughout the study, with orthophosphate values always less than 10 $\mu \mathrm{g} . \mathrm{L}^{-1}$ (Table 3). However, these levels were not limiting for $R$. raciborskii, since the species has the capacity to store phosphorus and grow in concentrations that are limiting for other cyanobacteria (Jensen et al. 1994, Padisák 1997). This can explain the fact that blooms of this species followed mixed blooms of chroococcalean cyanobacteria (Microcystis spp.) found in the lake previously (V.R. Werner \& H.D. Laughinghouse IV - personal observation), corroborating with observations by Tucci \& Sant'Anna (2003) in blooms of Lake Garças (São Paulo, Brazil, 2335'15.00"S and 4639'38.12”W), where Microcystis aeruginosa (Kützing) Kützing was followed by $R$. raciborskii.

Table 2. Pearson correlation coefficients between abiotic variables and the first two axes of the PCA ordination $(n=26)$.

\begin{tabular}{llc}
\hline & \multicolumn{2}{c}{ Principal components } \\
\hline Variables & Axis 1 & Axis 2 \\
Temperature & -0.406 & -0.769 \\
Transparency & -0.843 & 0.227 \\
$\mathrm{pH}$ & 0.691 & -0.642 \\
Conductivity & 0.872 & 0.062 \\
Dissolved oxygen & 0.625 & -0.021 \\
Ammonium & -0.728 & 0.006 \\
Organic material & 0.826 & 0.159 \\
Total Explanation & $51.8 \%$ & $21.5 \%$ \\
\hline
\end{tabular}




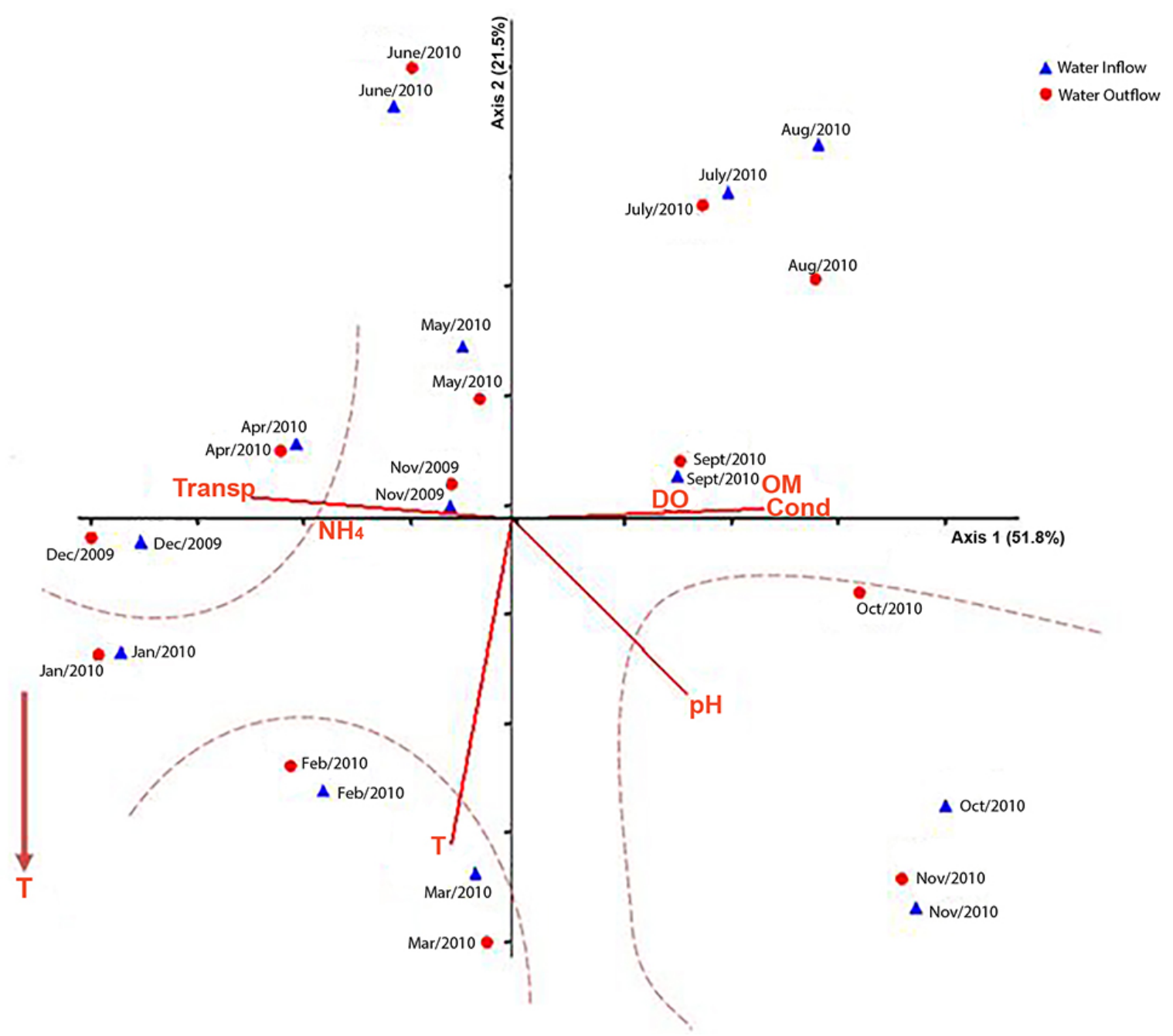

Fig. 6. Principal Component Analysis $(\mathrm{PCA})$ ordination of the sampling units $(\mathrm{P} 1)=$ water inflow and $(\mathrm{P} 2)=$ water outflow, and of the physical and chemical variables analyzed. The sampling units are listed by month abbreviated as follows: Jan = January; Feb $=$ February; Mar $=$ March; Apr $=$ April; May = May; Jun = June; Jul = July; Aug = August; Sept $=$ September; Oct $=$ October; Nov $=$ November; Dec $=$ December. $\mathrm{T}=$ Temperature; Transp $=$ Transparency; Cond $=$ Conductivity; DO = Dissolved oxygen; NH4 = Ammonium; OM = Organic material.

The organic matter in the lake ranged from 6.8-11.5 mg. $\mathrm{L}^{-1}$, with the minimum value found at the end of spring (outflow: December 2009) and the maximum recorded at both collection sites in spring (October 2010). The mean electrical conductivity was $152.1 \mu \mathrm{S} . \mathrm{cm}^{-1}$, with a minimum of $80.9 \mu{\mathrm{S} . \mathrm{cm}^{-1}}^{-1}$ in summer (February 2010) and maximum of $273.4 \mu{\mathrm{S} . \mathrm{cm}^{-1}}^{-1}$ in spring (October 2010), both at the inflow. Hence, the populations of $R$. raciborskii were able to tolerate large differences in ionic composition, which was also documented in the Ingazeira Reservoir (Pernambuco, Brazil) (Bouvy et al. 1999).

Researchers (e.g. Fogg et al. 1973, Pádisak 1997) have previously agreed that $R$. raciborskii develops in alkaline waters and does not occur in acidic waters. However, the $\mathrm{pH}$ of the water in our study varied from (5.4)5.6-8.7 and the densities of $R$. raciborskii were high, reaching 89,964 ind. $\mathrm{mL}^{-1}$ at $\mathrm{pH}$ 5.4; 72,285 ind. $\mathrm{mL}^{-1}$ and 99,994 ind. $\mathrm{mL}^{-1}$ at $\mathrm{pH}$ 5.6; and 61,400 ind. $\mathrm{mL}^{-1}$ at $\mathrm{pH}$ 8.7. In a study on the Pequeno River (233' $52.16^{\prime \prime} \mathrm{S}$ and $46^{\circ} 45^{\prime} 14.16^{\prime \prime} \mathrm{W}$ São Paulo, Brazil), a pH of 5.4 was recorded during a $R$. raciborskii bloom (Souza et al. 1998); however, the authors found that chlorophytes then became abundant, which did not occur in our study since $R$. raciborskii densities were persistently high. In Brazilian water bodies, high densities of $R$. raciborskii usually occur in alkaline waters, with $\mathrm{pH}$ varying between 8 and 9.4 (Bouvy et al. 1999, Huszar et al. 2000, Costa et al. 2006, Gemelgo et al. 2008). Nevertheless, blooms have also been recorded in slightly acidic to alkaline waters, with pH between 6 and 10 (Branco \& Senna 1994, Komárková et al. 1999, Tucci \& Sant'Anna 2003, Hepp 2009). These results, in addition to ours, indicate that $R$. raciborskii has a broad tolerance to $\mathrm{pH}$. 
Table 3. Abiotic variables recorded in the two samplings sites (water inflow and outflow) of the studied lake, from November 2009 to November 2010 , with mean and standard deviation (Mean $\pm \mathrm{SD})$. (ND = not detected, NM= not measured).

\begin{tabular}{|c|c|c|c|c|c|c|c|c|c|c|c|c|c|c|c|}
\hline \multirow{2}{*}{ Site } & \multirow{2}{*}{ Variables } & \multicolumn{13}{|c|}{ Month } & \multirow{2}{*}{ Mean \pm SD } \\
\hline & & Nov & Dec & Jan & Feb & Mar & Apr & May & Jun & Jul & Aug & Sep & Oct & Nov & \\
\hline \multirow{13}{*}{$\begin{array}{l}3 \\
0 \\
\text { 岕 } \\
\Xi\end{array}$} & Air temperature $\left({ }^{\circ} \mathrm{C}\right)$ & NM & 22.4 & 23.4 & 26 & 25.7 & 21.8 & 18.1 & 21.3 & 13.5 & 11.2 & 19 & 20.3 & 23.1 & $20.5 \pm 4.5$ \\
\hline & $\begin{array}{l}\text { Water temperature } \\
\left({ }^{\circ} \mathrm{C}\right)\end{array}$ & 22.8 & 23.4 & 27.2 & 28 & 26.6 & 23.5 & 19.4 & 15.5 & 13.3 & 13 & 19.4 & 24.2 & 24.3 & $21.6 \pm 5.1$ \\
\hline & $\mathrm{pH}$ & 6.3 & 6 & 6 & 6.7 & 7.8 & 5.9 & 6 & 5.6 & 6.7 & 6.5 & 6.7 & 8.2 & 8.7 & $6.7 \pm 1$ \\
\hline & Ammonium $\left(\mu \mathrm{g} . \mathrm{L}^{-1}\right)$ & 60 & 630 & 520 & 400 & 510 & 440 & 500 & 400 & 300 & 280 & 260 & 180 & 160 & $380 \pm 150$ \\
\hline & Nitrate $\left(\mu \mathrm{g} . \mathrm{L}^{-1}\right)$ & ND & 1,200 & 1,000 & 1,000 & 1,100 & 1,000 & 1,000 & 1,000 & 1,000 & 1,000 & 1,000 & 1,300 & 1,000 & $1,050 \pm 100$ \\
\hline & Nitrite $\left(\mu \mathrm{g} . \mathrm{L}^{-1}\right)$ & ND & ND & ND & ND & ND & ND & ND & ND & ND & ND & ND & ND & ND & ND \\
\hline & $\begin{array}{l}\text { Orthophosphate } \\
\left(\mu \mathrm{g} . \mathrm{L}^{-1}\right)\end{array}$ & ND & ND & ND & ND & ND & ND & ND & ND & ND & ND & ND & ND & ND & ND \\
\hline & $\begin{array}{l}\text { Dissolved oxygen } \\
\left(\mathrm{mg} . \mathrm{L}^{-1}\right)\end{array}$ & 6.40 & 6.50 & 4.00 & 6.70 & 8.20 & 7.20 & 9.00 & 2.50 & 9.80 & 9.00 & 9.00 & 8.30 & 7.80 & $7.30 \pm 2.10$ \\
\hline & DO saturation (\%) & 73.2 & 75.8 & 46.6 & 85.1 & 99.2 & 84 & 97 & 24.8 & 93 & 83.5 & 97 & 99 & 92.6 & $80.8 \pm 22.2$ \\
\hline & $\begin{array}{l}\text { Organic material } \\
\left(\mathrm{mg} \cdot \mathrm{L}^{-1}\right)\end{array}$ & 10 & 7.2 & 8.5 & 9.5 & 9.7 & 9.8 & 9.8 & 10.2 & 10.2 & 10.8 & 10.9 & 11.2 & 10.6 & $9.9 \pm 1.1$ \\
\hline & $\begin{array}{l}\text { Conductivity }(\mu \mathrm{S} \text {. } \\
\left.\mathrm{cm}^{-1}\right)\end{array}$ & 94.8 & 92.8 & 92.9 & 80.9 & 119 & 129 & 147 & 165 & 189 & 239 & 122 & 273.4 & 227.8 & $151.7 \pm 62.9$ \\
\hline & Transparency (m) & NM & 0.35 & 0.40 & 0.30 & 0.25 & 0.45 & 0.30 & 0.35 & 0.25 & 0.22 & 0.15 & 0.15 & 0.10 & $0.27 \pm 0.11$ \\
\hline & Depth (m) & NM & 0.40 & 0.40 & 0.35 & 0.40 & 0.50 & 0.40 & 0.35 & 0.40 & 0.30 & 0.33 & 0.40 & 0.27 & $0.37 \pm 0.06$ \\
\hline \multirow{13}{*}{$\begin{array}{l}3 \\
\stackrel{3}{0} \\
\stackrel{\leftrightarrows}{0} \\
0\end{array}$} & Air temperature $\left({ }^{\circ} \mathrm{C}\right)$ & NM & 20 & 21.8 & 24.2 & 26 & 25.3 & 20.2 & 21 & 9.5 & 11.6 & 16.9 & 20.4 & 22 & $19.9 \pm 5$ \\
\hline & $\begin{array}{l}\text { Water temperature } \\
\left({ }^{\circ} \mathrm{C}\right)\end{array}$ & 22.7 & 23.3 & 27.7 & 28 & 26.2 & 24.5 & 18.9 & 14.5 & 14.5 & 12.6 & 19.8 & 22.2 & 25.8 & $21.6 \pm 5.2$ \\
\hline & $\mathrm{pH}$ & 6.3 & 6.1 & 5.9 & 6.5 & 8.4 & 5.6 & 6.6 & 5.4 & 6.4 & 7.7 & 6.7 & 7.5 & 8.2 & $6.7 \pm 1$ \\
\hline & Ammonium ( $\mu$ g.L-1) & 60 & 660 & 520 & 430 & 500 & 400 & 500 & 400 & 330 & 280 & 240 & 140 & 150 & $379 \pm 157$ \\
\hline & Nitrate ( $\mu$ g.L-1) & ND & 1,200 & 1,000 & 1,000 & 1,100 & 1,000 & 1,000 & 1,000 & 1,000 & 1,000 & 1,000 & 1,200 & 1,000 & $1,000 \pm 100$ \\
\hline & Nitrite ( $\mu$ g.L-1) & ND & ND & ND & ND & ND & ND & ND & ND & ND & ND & ND & ND & ND & ND \\
\hline & $\begin{array}{l}\text { Orthophosphate } \\
(\mu \mathrm{g} . \mathrm{L}-1)\end{array}$ & ND & ND & ND & ND & ND & ND & ND & ND & ND & ND & ND & ND & ND & ND \\
\hline & $\begin{array}{l}\text { Dissolved oxygen } \\
(\mathrm{mg} . \mathrm{L}-1)\end{array}$ & 7.70 & 6.60 & 3.20 & 6.00 & 8.00 & 7.50 & 8.20 & 3.60 & 10.50 & 8.30 & 9.00 & 8.10 & 8.00 & $7.28 \pm 2.03$ \\
\hline & DO saturation (\%) & 88 & 77 & 36.6 & 76.2 & 98.6 & 89 & 88.4 & 35 & 97.1 & 99.7 & 99 & 97.6 & 98.6 & $83.1 \pm 22.5$ \\
\hline & $\begin{array}{l}\text { Organic material } \\
(\mathrm{mg} . \mathrm{L}-1)\end{array}$ & 10 & 6.8 & 8.5 & 9.5 & 8.8 & 9.8 & 9.8 & 10.2 & 10.2 & 10.5 & 11.4 & 11.5 & 10.8 & $9.8 \pm 1.3$ \\
\hline & $\begin{array}{l}\text { Conductivity ( } \mu \mathrm{S} \text {. } \\
\mathrm{cm}-1)\end{array}$ & 100 & 91.7 & 94.9 & 81.5 & 128 & 122 & 143 & 142 & 187 & 207 & 130 & 264.6 & 259.3 & $150.1 \pm 61.3$ \\
\hline & Transparency (m) & NM & 0.40 & 0.40 & 0.30 & 0.25 & 0.45 & 0.30 & 0.30 & 0.25 & 0.23 & 0.20 & 0.27 & 0.15 & $0.29 \pm 0.09$ \\
\hline & Depth (m) & NM & 0.40 & 0.40 & 0.35 & 1.90 & 1.80 & 1.75 & 1.75 & 1.90 & 1.95 & 2.00 & 1.85 & 1.85 & $1.49 \pm 0.67$ \\
\hline
\end{tabular}

\section{Toxicity}

Raphidiopsis raciborskii can produce both saxitoxins (neurotoxin) that inhibit nerve conduction causing paralysis and respiratory failure, and cylindrospermopsins (hepatotoxin) that can cause necrosis of the liver, kidneys, lung and gastric mucosa (Falconer et al. 1994). Saxitoxin production from toxic strains of the species has already been reported for several Brazilian waters, with the following variants: saxitoxin, neosaxitoxin, dc-saxitoxin, dc-neosaxitoxin, and gonyautoxins GTX-1, GTX-2, GTX3, GTX-4 and GTX-6 (Lagos et al. 1999, Bouvy et al. 1999, Yunes et al. 2003, Hepp 2009). Cylindrospermopsin has been documented in activated charcoal filter samples from a dialysis treatment in Caruaru, Pernambuco (Carmichael 2001, Marinho et al. 2005).
Saxitoxin (STX) and two gonyautoxin variants (GTX 2 and GTX 3) were present in the bloom (Table 4). The values were high when compared to the data available in the AGUAAN Program (Streamlining the Management and Use of Water with Harmful Algae) of the Cyanobacteria Research Unit of the Federal University of Rio Grande (FURG), Brazil, which has monitored surface waters in Rio Grande do Sul for ten years. In addition, our saxitoxin variants match the forms and quantities found in other studies throughout the State (Yunes et al. 2010). An important factor contributing to the toxic concentration of the bloom was the high density of $R$. raciborskii (> $1 \times 10^{6}$ cells. $\mathrm{mL}^{-1}$ ). 
Table 4. Cyanotoxins and Raphidiopsis raciborskii bloom densities (ind. $\left.\mathrm{mL}^{-1}\right)$ from the studied lake (STX = saxitoxin, GTX = gonyautoxin) sampled at the sites in November 2010.

\begin{tabular}{lccc}
\hline Sites & & Water Inflow & Water Outflow \\
\hline Bloom density (ind.mL $\left.{ }^{-1}\right)$ & & 83,504 & 61,400 \\
\hline & STX & 1.00 & 0.88 \\
Neurotoxins $\left(\mu \mathrm{g} . \mathrm{L}^{-1}\right)$ & GTX 2 & 3.50 & 3.06 \\
& GTX 3 & 3.18 & 2.65 \\
& STX (equivalents) & 4.29 & 3.67 \\
\hline
\end{tabular}

Blooms of Raphidiopsis raciborskii have been documented worldwide (as Cylindrospermopsis raciborskii) under different environmental conditions, from fresh to brackish waters, in tropical, subtropical and temperate zones, indicating that the species has a wide range of ecophysiological tolerances, corroborating the comments of Padisák (1997). This species is a more recent invader in temperate zones and its increase has been associated to climate change (e.g. Sinha et al. 2012). In addition to its adaptive strategies, the species is highly competitive in eutrophic environments, with the ability to form dense blooms and produce toxins. The ecological success of the species is related to: 1) migration in the water column; 2) tolerance to low light; 3 ) ability to use internal sources of phosphorus; 4) high absorption capacity of phosphorus and ammonia; 5) fixation of atmospheric nitrogen; 6) resistance to herbivory of zooplankton; 7) high dispersibility in rivers and especially in temperate lakes, via resistant akinetes, spread by birds and other agents; and 8) survival in slightly saline waters (Padisák 1997). The ammonium and phosphorus absorption capacity, as well as the ability to use internal sources of phosphorus, were key factors for bloom development of $R$. raciborskii. Furthermore, high competitiveness in eutrophic environments explains its excessive growth and consequent dominance, replacing mixed blooms formed by Microcystis aeruginosa, $M$. cf. brasiliensis (Azevedo \& Sant'Anna) Rigonato et al., $M$. protocystis Crow and Radiocystis fernandoi Komárek \& Komárková-Legnerová that had been observed earlier (since 2005) in this water body - (V.R. Werner \& H.D. Laughinghouse IV - personal observations).

The environmental conditions were favorable to maintain high densities of $R$. raciborskii in the lake throughout the study period. Due to the ability to produce toxins, these blooms are a permanent risk for aquatic biota, endangering animals that use lake water as a habitat, birds that use it as a resting and breeding area, and humans that use its surrounding area for recreational activities. Current studies on cyanobacterial blooms have proven their ability to produce aerosols containing cyanotoxins (Cheng et al. 2007, Stommel et al. 2013, Jang et al. 2020), a putative major human health threat for passersby and those that use contaminated lakes for leisure. These studies also indicate these aerosols as a risk factor for amyotrophic lateral sclerosis and cancer (Stommel et al. 2013, Zhang et al. 2015). As students and faculty are using this area for recreation, the possibility of exposure to both toxins and cyanobacteria through the air/wind is high, indicating the need for continued monitoring of this system and similar systems. This study provides insight into $R$. raciborskii bloom physiochemical ecology, which is appropriate for better management practices to mitigate harmful algal blooms.

\section{ACKNOWLEDGEMENTS}

To Research Support Foundation of the State of Rio Grande do Sul (FAPERGS) for the Scientific Initiation Grant to LM Silva (0786-2.03 / 09). To the Lutheran University of Brazil (ULBRA), campus Canoas, for permission to collect in the studied lake. To Manoel Luiz Nunes for the chemical analyses, Rosana Moreno Senna for identifying the trees and Ricardo Aranha Ramos for the map of the studied area. To Dr Fabiana Schneck for the valuable comments that improved the manuscript.

\section{REFERENCES}

Aguilera, A., Gómez, E.B., Kăstovský, J., Echenique, R.O. \& Salerno, G.L. 2018. The polyphasic analysis of two native Raphidiopsis isolates supports the unification of the genera Raphidiopsis and Cylindrospermopsis (Nostocales, Cyanobacteria). Phycologia 57(2):130-146.

American Public Health Association - APHA. 2005. Standards methods for the examination of water and waste water. American Public Health Association, Washington, USA.

Antunes, J.T., Leão, P.N \& Vasconcelos, V.M. 2015. Cylindrospermopsis raciborskii: review of the distribution, phylogeography and ecophysiology of a global invasive species. Frontiers in Microbiology 6:1-13.

Babanazarova, O.V., Sidelev, S.I. \& Fastner, J. 2015. Northern expansion of Cylindrospermopsis raciborskii (Nostocales, Cyanoprokaryota) observed in shallow highly eutrophic Lake Nero (Russia). International Journal on Algae 17(2):131-141.

Bormans, M. 1999. Controlling algal blooms in the Fitzroy River. Rivers for the Future 10:26-29.

Bouvy, M., Falcão, D. Marinho, M., Pagano, M. \& Moura, A. 2000. Occurrence of Cylindrospermopsis (Cyanobacteria) in 39 Brazilian tropical reservoirs during the 1998 drought. Aquatic Microbial Ecology 23:13-27.

Bouvy, M., Molica, R., Oliveira, S., Marinho, M. \& Beker, B. 1999. Dynamics of a toxic bloom (Cylindrospermopsis raciborskii) in a shallow reservoir in the semi-arid region of Notheast Brazil. Aquatic Microbial Ecology 20:285-297.

Branco, C.W.C. \& Senna, P.A.C. 1994. Factors influencing the development of Cylindrospermopsis raciborskii and Microcystis aeruginosa in the Paranoá Reservoir, Brasília, Brazil. Algological Studies 75:85-96. 
Bressan, F.A. 2001. Fatores reguladores da dominância de Cylindrospermopsis raciborskii (Woloszynska) Seenayya \& Subba Raju no reservatório Tabocas, Caruaru, PE. Dissertação. $66 \mathrm{f}$. Universidade. Federal do Rio de Janeiro, Rio de Janeiro.

Briand, J.F., Leboulanger, C., Humbert, J.F., Bernard, C. \& Dufour, P. 2004. Cylindrospermopsis raciborskii (Cyanobacteria) invasion at mid-latitudes: Selection, wide physiological tolerance, or global warming? Journal of Phycology 40:231-238.

Carmichael, W.W., Azevedo, S.M.F.O., An, J.S., Molica, R.J., Jochimsen, E.M., Lau, S., Rinehart, K.L., Shaw, G.R. \& Eaglesham. G.K. 2001. Human fatalities from cyanobacteria: chemical and biological evidence for cyanotoxins. Environmental Health Perspectives 109:663-668

Cheng, Y.S., Zhou, Y., Irvin, C.M., Kirkpatrick, B. \& Backer, L.C. 2007. Characterization of aerosols containing microcystin. Marine Drugs 5:136-150.

Codd, G.A. \& Bell, S.G. 1984. Eutrophication and toxin cyanobacteria in fresh waters. Water Pollution Control 84:225-232.

Costa, I.A.S., Azevedo, S.M.F.O., Senna, P.A.C., Bernardo, R.R., Costa, S.M. \& Chellappa, N.T. 2006. Occurrence of toxin-producing cyanobacteria blooms in a Brazilian semiarid reservoir. Brazilian Journal Biology 66:211-219.

Dokulil, M.T. \& Mayer, J. 1996. Population dynamics and photosynthetic rates of a Cylindrospermopsis - Limnothrix association in a highly eutrophic urban lake, Alte Donau, Austria. Algological Studies 83:179-195.

Fabbro, L.D. \& Duivenvoorden, L.J. 1996. Profile of a bloom of the cyanobacterium Cylindrospermopsis raciborskii (Woloszynska) Seenaya and Subba Raju in the Fitzroy River in tropical Central Queensland. Marine and Freshwater Research 47:685-694.

Falconer, I.R., Brunch, M.D., Steffensen, D.A. Choice, M.E \& Coverdale, O.R. 1994. Toxicity of the blue green algae (cyanobacterium) Microcystis aeruginosa in drinking water to growing pigs, as an animal for human injury and risk assessment. Environmental Toxicology and Water Quality 9:131-139.

Falconer, I.R. \& Fitzgerald, J. 1999. Human health aspects. In: Toxic cyanobacteria in water: A guide to their public health consequences, monitoring and management (Chorus, I. \& Bartram, J., eds.). Routledge, London, p. 113-153.

Fogg, G.E., Stewart, W.D.P., Fay, P. \& Walsby, A.E. 1973. The blue-green algae. Academic Press, London-New York. 459 p.

Gemelgo, M.C.P, Sant'Anna, C.L., Tucci, A. \& Barbosa, H.R. 2008. Population dynamics of Cylindrospermopsis raciborskii (Woloszynska) Seenayya \& Subba Raju, a Cyanobacteria toxic species, in water supply reservoirs in São Paulo, Brazil. Hoehnea 35:297-307.

Grellmann, C. 2006. Aspectos da morfologia e ecologia de Cylindrospermopsis raciborskii (Woloszinska) Seenayya et Subba Raju e produção de cianotoxinas na lagoa do Peri, Florianópolis, SC, Brasil. Dissertação. 94 f. Universidade Federal de Santa Catarina, Florianópolis.

Hepp, K. 2009. Composição, variação temporal e espacial de cianobactérias, com ênfase na espécie Cylindrospermopsis raciborskii (Woloszynska) Seenayya et Subba Raju no lago do parque Professor Theobaldo Dick, Lajeado, Rio Grande do Sul, Brasil. Dissertação. $82 \mathrm{f}$. Universidade do Vale do Taquari, Lajeado.

Hoff-Risseti, C., Dörr, F.A., Schaker, P.D.C. Pinto, E., Werner, V.R. \& Fiore, M.F. 2013. Cylindrospermopsin and saxitoxin synthetase genes in Cylindrospermopsis raciborskii strains from Brazilian freshwater. Plos One 8:1-14.

Huszar, V.L.M., Silva, L.H.S., Marinho, M., Domingos, P. \& Sant'Anna, C.L. 2000. Cyanoprokaryote assemblages in eight productive tropical Brazilian waters. Hydrobiology 424:67-77.

Jang, M., Berthold, D.E., Yu, Z., Silva-Sanchez, C., Laughinghouse IV, H.D., Denslow, N. \& Han, S. 2020. Atmospheric Progression of Microcystin-LR from Cyanobacterial Aerosol. Environmental Science and Technology Letters. doi: 10.1021/acs.estlett.0c00464.

Jensen, J.P., Jeppesen, E., Olrik, K. \& Kristensen, P. 1994. Impact of nutrients and physical factors on the shift from cyanobacterial to chlorophyte dominance in shallow Danish lakes. Canadian Journal of Fisheries and Aquatic Sciences 51:1692-1699.
Jones, W.W. \& Sauter, S. 2005. Distribution and abundance of Cylindrospermopsis raciborskii in Indiana lakes and reservoirs. School of Public and Environmental Affairs, Indiana University, Bloomington. $54 \mathrm{p}$.

Kokociński, M., Stefaniak, K., Mankiewicz-Boczek, J., Izydorczyk K. \& Soininen, J. 2010. The ecology of the invasive Cylindrospermopsis raciborskii (Nostocales, Cyanophyta) in two hypereutrophic lakes dominated by Planktothrix agardhii (Oscillatoriales, Cyanophyta). European Journal of Phycology 45(4):365-374.

Komárek, J. \& Anagnostidis, K. 1989. Modern approach to the classification system of cyanophytes 4 - Nostocales. Archiv für Hydrobiologie/Supplements 82(3), Algological Studies 56:247-345.

Komárková, J. 1998. The tropical planktonic genus Cylindrospermopsis (Cyanophytes, Cyanobacteria). In: Congresso Latino-Americano de Ficologia 4., 1996, Caxambu. Anais... São Paulo: Sociedade Ficológica da América Latina e Caribe. p. 327-340.

Komárková, J., Silva, R.L. \& Senna, P.A.C. 1999. Extreme morphology of Cylindrospermopsis raciborskii (Nostocales, Cyanobacteria) in the Lagoa do Peri, a freshwater coastal lagoon, Santa Catarina, Brazil. Algological Studies 94:207-222.

Lagos, N., Onodera, H., Zagatto, P.A., Andrinolo, D., Azevedo, S.M.F.O. \& Oshima, Y. 1999. The first evidence of paralytic shellfisch toxins in the freshwater cyanobacterium Cylindrospermopsis raciborskii, isolated from Brazil. Toxicon 37:1359-1373.

Lobo, E. \& Leighton, G. 1986. Estruturas comunitarias de las fitocenoses planctonicas de los sistemas de desembocaduras de rios y esteros de la zona central de Chile. Revista de Biologia Marinha 22:1-29.

Marinho, M.M., Molica, R.J.R., Jardim, F.A. \& Huszar, V.L.M. 2005. Cylindrospermopsis (Cyanobacteria) em Ecossistemas Brasileiros: Um novo desafio para o gerenciamento aquático. In Lições de Limnologia F. Roland, D. César, \& M. MARINHO, eds. Rima, São Paulo, p. 325-339.

McGregor, G.B. \& Fabbro, L.D. 2000. Dominance of Cylindrospermopsis raciborskii (Nostocales, Cyanoprokaryota) in Queensland tropical and subtropical reservoir: Implications for monitoring and management. Lakes \& Reservoir: Research and Management 5:195-205.

Miller, V.V.K. 1923. Sistematike roda Anabaena Bory. Russkiĩ arkhiv protistologii. 2:116-126.

Molica, R., Onodera, H., García, C., Rivas, M., Andrinolo, D., Nascimento, S., Meguro, H., Oshima, Y., Azevedo, S.M.F.O. \& Lagos, N. 2002. Toxins in the freshwater cyanobacterium Cylindrospermopsis raciborskii (Cyanophyceae) isolated from Tabocas reservoir in Caruaru, Brazil, including demonstration of a new saxitoxin analogue. Phycologia 41:06-611.

Moustaka-Gouni, M., Kormas, K.A., Vardaka, E., Katsiapi M., \& Gkelis, S. 2009. Raphidiopsis mediterranea Skuja represents non-heterocytous life-cycle stages of Cylindrospermopsis raciborskii (Woloszynska) Seenayya et Subba Raju in Lake Kastoria (Greece), its type locality: Evidence by morphological and phylogenetic analysis. Harmful Algae 8(6):864-872.

Oshima, Y. 1995. Postcolumn Derivatization Liquid - Chromatographic method for paralytic shellfish toxins. Journal of AOAC International 78:528-532.

Padisák, J. 1997. Cylindrospermopsis raciborskii (Woloszynska) Seenayya et Subba Raju, an expanding, highly adaptive cyanobacterium: worldwide distribution and review of its ecology. Archiv für Hydrobiologie 107:563-593.

Padisák, J. \& Reynolds, C.S. 1998. Selection of phytoplankton associations in Lake Balaton, Hungary, in response to eutrophication and restoration measures, with special reference to the Cyanoprokaryotes. Hydrobiologia 384:41-53.

Pappas, J.L. \& Stoermer, E.F. 1996. Quantitative method for determining a representative algal sample count. Journal of Phycology 32:693-696.

Présing, M., Herodek, S., Vörös, L. \& Kóbor, I. 1996. Nitrogen fixation, ammonium and nitrate uptake during a bloom of Cylindrospermopsis raciborskii in Lake Balaton. Archiv für Hydrobiologie 136:553-562.

Seenayya, G. \& Subba RAJU, N. 1972. On the ecology and systematic position of the alga know as Anabaenopsis raciborskii (Wolosz.) Elenkin and a critical evaluation of the forms described under the genus Anabaenopsis. In Taxonomy and biology of blue-green algae, (T.V. Desikachary, ed.) Madras, p. 52-57. 
Sinha, R., Pearson, L.A., Davis, T.W., Burford, M.A., Orr, P.T. \& Neilan, B.A. 2012. Increased incidence of Cylindrospermopsis raciborskii in temperate zones - Is climate change responsible? Water Research 46:1408-1419.

Souza, R.C.R., Carvalho, M.C. \& Truzzi, A.C. 1998. Cylindrospermopsis raciborskii (Wolosz.) Seenayya et Subba Raju (Cyanophyceae) dominance and a contribution to the knowledge of Rio Pequeno arm, Billings reservoir, Brazil. Environmental Toxicology and Water Quality 13:73-81.

Stommel, E.W., Field, N.C. \& Caller, T.A. 2013. Aerosolization of cyanobacteria as a risk factor for amyotrophic lateral sclerosis. Medical Hypotheses 80:142-145.

Tucci, A. \& Sant'Anna, C.L. 2003. Cylindrospermopsis raciborskii (Woloszynska) Seenaya and Subba Raju (Cyanobacteria): variação semanal e relações com fatores ambientais em um reservatório eutrófico, São Paulo, SP, Brasil. Revista Brasileira de Botânica 26:97-112.

Utermöhl, H. 1958. Zur Vervollkommung der Quantitativew Phytoplankton Metodik. Mitteilugen der Internationalen Vreinigung für Theoretische und Angewandle. Limnologie 9:1-38.
Valentin, J.L. 2000. Ecologia Numérica: Uma Introdução à análise multivariada de dados ecológicos. Interciência, Rio de Janeiro. 154 p.

Vörös, L. 1995. A kékalgák elszaporodását befolyásoló tényezök és toxicitásuk kutatása [Factors affecting growth and toxicity of cyanobacteria]. Ministry for Environment and Regional Affairs, Research Report, Budapest. 204 p.

Woloszynska, J. 1912. Das Phytoplankton einiger javanischer Seen, mit Berücksichtigung des Sawa-Planktons. Bulletin international de l'Académie des Sciences de Cracovie. Mathématiques et Naturelles. Série B, Cracovie, p. 649-709.

Yunes, J.S., Cunha, N.T., Proença, L.A.O., Barros, L.P.C. \& Montserrat, J.M. 2003. Cyanobacterial neurotoxins from Southern Brazilian fresh waters. Comments on Toxicology 9: 103-115.

Yunes, J.S., Leão, J.C., Colvara, W.A., Bif, M. \& Kolbe, G. 2010. Toxin production by Cyanobacteria in south Brazilian reservoirs. In International Conference on Toxic Cyanobacteria (ICTC8). Book of abstract p. 219.

Zhang, F., Lee, J., Liang, S. \& Shum, C. 2015. Cyanobacteria blooms and non-alcoholic liver disease: evidence from a county level ecological study in the United States. Environmental Health 14:2-11. 